\section{OPEN 0 ACCESS}

DOI: $10.25040 / n t s h 2020.02 .05$

Для листування:

Лакнау, Індія

E-пошта: drlatikagupta@gmail.com

Стаття надійшла: 29.09.2020

Прийнята до друку: 12.10.2020

Опублікована онлайн: 23.11.2020

CC) C) Прітхві Санджіквкумар
Гаур, Латіка Гупта,
2020

Особистий внесок авторів:

Всі автори в рівній мірі брали участь у підготовці цього огляду. Всі автори прочитали та затвердили остаточний варіант рукопису.

Конфлікт інтересів: Автори декларують, що немає конфлікту інтересів.

Фінансування: Підготовка цього огляду не потребувала фінансування.

Дозвіл біоетики: Для даного огляду не потрібний.

зрозуміти хворобу та її вплив різноманітні умови, ситуація також вимагає пильного спостереження за поширенням неправдивою інформації, помилкових звітів і неетичних досліджень. Крім того, що максимально зменшити ризик для пацієнтів і лікарів, потрібно розробити перевірені інструменти для віддаленого оцінювання.

У цій статті ми обговорюємо ймовірні зміни та потенційні сфери помилково звітування про дослідження, пропонуючи можливі рішення для плідних досліджень у період пандемії. Ми також визначаємо нові методи проведення досліджень і невдачі, з якими можуть зіткнутися дослідники під час виконання таких завдань, зокрема етичного та фінансового характеру. Ми сподіваємося, вони допоможуть сформувати перспективи для досліджень і допоможуть здійснювати етичні та дійсні дослідження в цей особливо складний час.

Ключові слова: коронавірус, дослідження, неправдива інформація, соціальні мережі, етика 


\title{
Changing research paradigm in the face of a global pandemic: foreseeable impact and adaptive measures in academic research in the future
}

\author{
Prithvi Sanjeevkumar Gaur ${ }^{1}$, Latika Gupta ${ }^{2}$ \\ ${ }^{1}$ Smt. Kashibai Navale Medical College and General Hospital, \\ Pune, India. \\ 2 Department of Clinical Immunology and Rheumatology, \\ Sanjay Gandhi Postgraduate Institute of Medical Sciences \\ Lucknow, India
}

The Coronavirus disease 2 (COVID-19) pandemic has led to a massive rise in research in a bid to understand more about the new disease and better cope with the pandemic. The need for social distance and limited human movement in open spaces since the COVID-19 outbreak has brought most forms of research to a standstill. While most research incentives have been directed towards research regarding the pandemic, diminished patient visits, have paralysed all the studies requiring personal and physical examination. The majority of social interactions have been reduced to a screen, and this is also the new practice in the research realm.

This unique situation calls for a need to re-examine research practices and reinvent novel methods for quality research. While it is prudent to step up research to understand the disease and its impact on varied conditions, the situation also necessitates a close watch for misinformation, erroneous reporting, and failure of ethical research. Moreover, there is a need to derive validated tools for remote assessment to minimise risk to patients and physicians alike.

In this brief, we discuss the perceived changes and potential areas for erroneous research reporting while providing possible solutions for fruitful research in the peri-pandemic period. We also identify new methods for conducting studies and setbacks that could be faced while carrying out such tasks, including those of methodological, ethical and financial nature. We hope these may shape researcher perspectives and help them conduct ethical and valid research in these particularly trying times.

Keywords: Coronavirus, research, misinformation, social Media, ethics

Cite this article as: Gupta L, Sanjeevkumar Gaur P. Changing research paradigm in the face of A global pandemic: Foreseeable impact and adaptive measures in academic research in the future. Proc Shevchenko Sci Soc Med Sci. 2020; 62(2). 62-68. 
Introduction The world has been inflicted with the rather unpredicted and sudden outbreak of the COVID-19 strain of the coronavirus. To protect the human race from being wiped out, new social rules are being followed post lockdown relaxations across the world. Social distancing, the constant use of masks and sanitizers and the maintaining of personal hygiene is being advocated now more than ever. This has left the world in a state of panic and material as well as immaterial loss [1]. The research world too has faced a massive setback as the ongoing clinical and laboratory researches have come to a standstill. New research studies skewed towards finding more about the COVID-19 strain or its cure and vaccine have been introduced and have taken the foreground $[2,3]$. To carry out research, the methodologies used need change in coherence with the global economic meltdown that will cause costs to soar, compounded by an increased usage of protective gear. Social distancing and infrequent visits to the hospital will also mandate increasing use of technology for conducting research. Remote methods of research, such as surveys and those with selfmonitoring, self-examining and self-reporting methods will be commonplace $[4,5]$

The ethical guidelines will have to be tweaked to cater to the extraordinary conditions as well. Amid the surge in the publication of literature regarding COVID - 19, unethical practices like redundant research, salami research or plagiarism should be looked out for as this sensitive situation can act as a gateway for a rise in unethical researchers [6]. Research is the backbone of all new medical innovations, practices and therapies. Without meaningful, progressive research the medical field will be paralysed. Therefore, to adapt to the situation and innovate to find new ways of carrying out the same research with fewer or no compromises on the anticipated results is the need of the hour.

The objective of this paper is to identify the areas of research that may be affected in the pandemic period and to predict possible solutions for ethical, valid and useful research [7].

\section{Patient visits}

Previously, one of the easiest ways to carry out research was to collect data from a pool of patients, manually and personally, reducing the chances of errors and increasing the accuracy and applicability of a research. Doctors, physicians and researches would easily carry out trials and studies requiring the patient to report the clinic or hospital at regular intervals. Here, the physician could personally analyse the patient for progress. However, in the current environment, investigators have had to adapt to newer styles of research. The drastic change in lifestyle post the lockdown makes asking patients to report regularly, in person to the hospital is rather inhuman and much contrary to the natural instinct of a doctor to protect and save lives [8]. Therefore, data collection is being done using various technological aids like video calls, online messaging systems and phone calls $[9,10]$. This is currently, the easiest and most convenient way to collect data, stay in contact and consult patients. The patients can be instructed on ways to examine themselves and report the findings leaving the physicians dependent on their observatory and intuitive skills. Subjective errors could be negated by asking the patient to make multiple self-examinations and their relatives or family or co-residents must also be asked to examine the patient. Leading questions must be avoided while doing the same as this allows the examiner to report the finding in a personalised manner without any bias. Device based outcome measures of disease assessment may grain greater foothold in the coming times $[11,12]$. The future holds a rather unclear picture however, it can be predicted that the numbers being received by hospitals will reduce drastically and local consultation or e-consultations will be the new normal. Thus, studies using survey methodologies or those that are minimally affected my self - reporting of examination results will be more popular as compared to clinical trials [13]. Study pools will be massively affected by the enthusiasm and willingness of the target population. Thus, the persuasive skills of the physician will be at test [14].

The unique challenge posed by illiteracy and poor penetrance are another unchartered area in the developing countries. In countries like India with a heterogenous population, widely varying socio-economic strata, and over 400 dialects, this can be a significant hurdle in reaching out to patients, who may need assistance from family members, which are likely to be at work in the daytime when the clin- 
ics are active. However, the comfort of talking from home in a snug environment can put the patients at ease and may help with better communication in certain instances. The determinants of smooth teleconsultation delivery need exploration in the future, for better clinical care from a distance [15].

\section{Data collection}

In times of precarious research funding and downsizing of clerical and research staff, electronic means of data recording, organising and analysis may take precedence over manual methods. The use of electronic case record forms with survey-based data collection may reduce manual work. Various portals offer free electronic data collection system along with advanced paid options at nominal fees. Portals like SurveyMonkey, Google forms, YesInsights, Surveygizmo and SurveyPlanet have free access to basic functions [16]. ClientHeartbeat is one such portal that gives exclusive access to only paid members. These portals not only provide pre-designed templates and advanced display accents like progress bars but also have advanced answer options. These tools allow the exporting of analysed data making data cleaning obsolete [17]. The use of these tools must however, cater to the aesthetic sensibilities of the target population and thus, the portal of choice must be selected keeping that in mind. These may also allow structured case record forms to be synced with organic survey based electronic forms to conveniently conduct collaborative research $[18,19]$

\section{Methods of Research}

Initially, increase in case reports and surveys will be observed as the various clinical presentations of COVID-19 patients will be reported to form a pool of expected symptoms and the treatment plan followed $[13,20,21]$. This pool can then be extrapolated to form and prove various hypotheses. Thus, the methodology of research will shift towards compilation of evidence from square tone, gradually building onto original cohort studies and laboratory-based research $[7,22]$. Since, majority of the study methodologies do not support long distance participation, the use of surveys will become more popular. This is because, surveys not only support long distance participation but also allow the involvement of a large and diverse cohort with global reach. The use of sur- veys may allow study to take place at the convenience of the investigator and participant.

The paucity of patient visits may limit new data collection, and thus, the use of old databases may also increase. Investigators may be tempted to reanalyse existing data leading to inaccurate, dated conclusions that may or may not be extrapolated to clinical practice or advanced research. Meanwhile artificial intelligence-based algorithms may come handy in novel and innovative means of research [19]. With everything moving online, social media is the new frontier, for academic reading, research as well as post-publication promotions of scholarly research [4, 23].

\section{Ethics}

Prior to the outbreak of the COVID-19 strain of the coronavirus, taking well informed consent was done in person. Since, that is now rather difficult, it can be done over a phone call or video call. The course and duration of this outbreak being unknown and unpredictable, living with it, seems to be the smart way to proceed. Therefore, ethical boards must update their guidelines [24]. They must include guidelines for clear reporting of protection standards used to protect the private records of patients that have been revealed on a video call or the internet. Along with the advent of applications and creation of hospital specific software and clouds, the danger of leaking of information or hacking of hospital systems must be considered while taking the consent of the patient. Release of the private documents of patients into public domain is a matter of breach of confidentiality and must be handled as such $[25,26]$.

The well informed, written and signed consent of patients is a key procedure during studies. The use of e-mails or scanned copies of the same should serve the purpose of proving the consensual participation of the individual. The written, informed signed consent must clearly state the details of the patient and the investigator. The consent form must include that the patient knows the purpose of the study and the predicted outcome along with the possible adverse effects and risks. Additionally, it must also include the purpose of distance participation and confirm that the patient is willing to self-examine and accurately report their findings in a timely and appropriate manner [27]. 
Safety of staff conducting research is another major concern [28].

These difficult, unforeseen circumstances may encourage or coerce people into improving their number of publications by publishing salami publications. Thus, the publication guidelines must also be improved and updated to reduce unethical publishing practices. Along with salami publications, the temptation to publish redundant papers or practice plagiarism may also increase [29]. This must intercepted by the ethical board at the nascent stages itself [30]. A stringent peer review is vital to valid and ethical research in these testing times [31].

Various institutes and organisations in the world can take up the task of collecting data and initiating collaborative efforts. This allows holistic and global approaches to study of diseases and better conclusions will be reached. Various organisations are now keeping updated information and databases on COVID-19 to facilitate research.

Multiple collaborations like the COVID-19 Global Rheumatology Alliance, the Global Alliance of Medical Excellence and the Global Alliance of Chronic Diseases bring together a community with a shared vision, collecting, analysing and disseminating coalesced information [32, 33]. This helps to bring about the spirit of collaboration in the medical community and improves the quality of research. Portals similar to Covidence also help to allow multiple researches to work simultaneously on the same project [34]. They bring together investigators of the same field from different parts of the world and reduce the time taken on each project bringing better yield.

\section{Funding}

With the coronavirus outbreak, has come the largest global recession seen since the second World War.(24)(23)(19) The world bank predicts the global GDP to fall by $5.2 \%$ this year while the certainty to find a cure or vaccine by the end of this year is unknown. Therefore, the funds released to support research not skewed towards community health or COVID-19 will be minimal if not negligible [20]. In such a scenario, carrying out research requiring minimal funds and based more on the pre-existing resources is more responsible [36].
Requesting funds for research and hoping to get them is rather improbable now due to the predicted oncoming recession.(37) However, the need of more instruments so as to provide them to the patients for self-examining, the use of protective gear and most importantly the updating of hospital databases and the need of upgraded technology all increase the costs manifold.(38) The need for a balanced and prioritized expenditure is the need of the hour as most obviously, the expenses will increase. Research funds must be concentrated and coalesced to allow at least a small number of researches if not all to be carried out without any hiccups. The financial situation in the developing world would rather be grim, and aids may be slow to come [39].

Research should be prioritized and the quality of research must be upheld. The research regarding COVID-19 is the need of the hour. However, post COVID, research concentrating on community health, disaster management and pandemic prediction may increase $[40,41]$.

\section{Conclusion}

New situations call for newer methods. The humankind is known for evolving and therefore, the COVID-19 pandemic has brought with it the need for humankind to adapt and evolve. The post COVID world is still not seen and unknown and unpredictable, therefore all we can do is predict and hypothesize. With a sudden change, new methodologies will have to be adopted and methods allowing social distancing and self-reliance in a patient might take over. Our knowledge, experience and skills will be required now more than ever to diagnose and treatment from afar. Research cannot halt and therefore, inexpensive, viable, sustainable and accurate methods must be adopted to yield accurate and dependable data and conclusions. Ethical, accurate practices should be followed and appropriate data must be published. The use of surveys and tele-reporting may be adopted. Studies must become technologically friendly and software to support medical care online must be developed. Artificial intelligence could also be used. Improved transparency and strengthening of the healthcare chain will also be undertaken to support the easy reporting of study findings. Thus, the pandemic will not deter the healthcare industry but improve it. 


\section{References}

1. Rewari BB, Mangadan-Konath N, Sharma M. Impact of COVID-19 on the global supply chain of antiretroviral drugs: a rapid survey of Indian manufacturers. WHO South East Asia J Public Health. 2020;9(2):126-33.

2. Wang M, Wu T, Zuo Z, et al. BMJ Supportive \& Palliative Care Epub ahead of print: [2020]. doi:10.1136/ bmjspcare-2020-002554

3. Shi Q, Zhou Q, Wang X, Liao J, Yu Y, Wang Z, et al. Potential effectiveness and safety of antiviral agents in children with coronavirus disease 2019: a rapid review and meta-analysis. Ann Transl Med. 2020 May;8(10):624.

4. Haldule S, Davalbhakta S, Agarwal V, Gupta L, Agarwal V. Post-publication promotion in rheumatology: a survey focusing on social media [published online ahead of print, [2020]. Rheumatol Int. 2020;1-8. doi:10.1007/s00296-020-04700-7

5. Islam JY, Camacho-Rivera M, Vidot DC. Examining COVID-19 Preventive Behaviors among Cancer Survivors in the United States: an analysis of the COVID-19 Impact Survey. Cancer Epidemiol Biomarkers Prev. 2020:cebp.0801.2020. doi: 10.1158/1055-9965.EPI-20-0801. Epub ahead of print. PMID: 32978173

6. Misra DP, Ravindran V. Publication misconducts related to copyright : tread carefully to avoid falling ! J R Coll Physicians Edinb 2020; 50: 3-5

7. Buss LF, Prete CA, Abrahim CM, Mendrone A, Salomon T, Almeida-Neto C de, et al. COVID-19 herd immunity in the Brazilian Amazon. medRxiv. 2020 21;2020.09.16. DOI: https://doi. org/10.1101/2020.09.16.20194787

8. Tang Z, Dubois S, Soon C, Agrawal D. A model for the pandemic and beyond: Telemedicine for all outpatient gastroenterology referrals reduces unnecessary clinic visits. J Telemed Telecare. 2020:1357633X20957224. doi: 10.1177/1357633X20957224. Epub ahead of print. PMID: 32954940.

9. Andujar M, Roura E, Torres A and the HPV Canary Study Group, et al Prevalence and genotype distribution of cervical human papilomavirus infection in the pre-vaccination era: a population-based study in the Canary Islands BMJ Open 2020;10:e037402. doi: 10.1136/bmjopen-2020-037402

10. Costa L, Tasso M, Scotti N, Mostacciuolo E, Girolimetto N, Foglia F, Del Puente A, Scarpa R, Caso F. Telerheumatology in COVID-19 era: a study from a psoriatic arthritis cohort. Ann Rheum Dis. 2020: annrheumdis-2020-217806. doi: 10.1136/annrheumdis-2020-217806. Epub ahead of print. PMID: 32527866

11. Gupta, Latikaa; Chinoy, Hectorb,c,d Monitoring disease activity and damage in adult and juvenile idiopathic inflammatory myopathy, Current Opinion in Rheumatology: 2020 - Volume Publish Ahead of Print - Issue -doi: 10.1097/BOR.0000000000000749

12. Davalbhakta S, Advani S, Kumar S, et al. A Systematic Review of Smartphone Applications Available for Corona Virus Disease 2019 (COVID19) and the Assessment of their Quality Using the Mobile Application Rating Scale (MARS). J Med Syst. 2020;44(9):164. Published 2020. doi:10.1007/s10916-020-01633-3

13. Gupta L, Gasparyan AY, Misra DP, Agarwal V, Zimba O, Yessirkepov M. Information and Misinformation on COVID-19: a Cross-Sectional Survey Study. J Korean Med Sci. 2020 ;35(27):e256. doi: 10.3346/ jkms.2020.35.e256. PMID: 32657090; PMCID: PMC7358067.

14. Abdul Rahim HF, Ismail SI, Hassan A, Fadl T, Khaled SM, Shockley B, et al. Willingness to participate in genome testing: a survey of public attitudes from Qatar. Journal of Human Genetics. 2020;1-7.

15. Ball HL. About research : conducting online surveys. Journal of human lactation. 2019;35(3):413-7.

16. Agarwal V, Gupta L, Davalbhakta S, Misra DP, Agarwal V, Goel A. Prevalent fears and inadequate understanding of COVID-19 among medical undergraduates in India: results of a web-based survey. J R Coll Physicians Edinb. 2020;50(3):345-6.

17. Eysenbach G, Wyatt J Using the Internet for Surveys and Health Research J Med Internet Res 2002;4(2):e13 DOI: 10.2196/jmir.4.2.e13 PMID: 12554560 PMCID: PMC1761932

18. Pankti Mehta, Latika Gupta. Combined case record forms for collaborative datasets of patients and controls of idiopathic inflammatory myopathies. Indian J Rheumatol 2020. [Published ahead of print]. DOI: 10.4103/injr.injr_56_20

19. Kharbanda R, Naveen R, Misra DP, Agarwal V, Gupta L. Combined Case Record Forms for Collating Obstetric Outcomes in Rare Rheumatic Diseases. Indian Journal of Rheumatology. DOI: 10.4103/injr. injr_102_20

20. Gupta V, Bhoyar RC, Jain A, Srivastava S, Upadhayay R, Imran M, et al. Asymptomatic reinfection in two healthcare workers from India with genetically distinct SARS-CoV-2.Clin Infect Dis 2020. doi 10.1093/ cid/ciaa1451

21. Choi EM, Chu DKW, Cheng PKC, Tsang DNC, Peiris M, Bausch DG, et al. In-flight transmission of severe acute respiratory syndrome coronavirus 2. Emerg Infect Dis. 2020 Nov [cited 2020]. DOI: 10.3201/ eid2611.203254 
22. Zhang Q, Bastard P, Liu Z, Pen JL, Moncada-Velez M, Chen J, et al. Inborn errors of type I IFN immunity in patients with life-threatening COVID-19. Science [Internet]. 2020[cited 2020]. DOI: 10.1126/science. abd4570

23. Ahmed S, Gupta L. Perception about social media use by rheumatology journals: Survey among the attendees of IRACON 2019. Indian J Rheumatol 2020;15:171-4

24. Bull S, Jamrozik $E$, Binik $A$, et al. SARS-CoV-2 challenge studies: ethics and risk minimisation. Journal of Medical Ethics Published Online First: 2020. doi: 10.1136/medethics-2020-106504

25. Williams CM, Chaturvedi R, Chakravarthy K. Cybersecurity Risks in a Pandemic. J Med Internet Res 2020;22(9):e23692. DOI: 10.2196/23692. PMID: 32897869

26. Goel A, Gupta L. Social Media in the Times of COVID-19. J Clin Rheumatol [Internet]. 2020 [cited 20 ]; doi : 10.1097/RHU.0000000000001508.

27. Bull S, Jamrozik E, Binik A, et al SARS-CoV-2 challenge studies: ethics and risk minimisation Journal of Medical Ethics Published Online First: 2020. doi: 10.1136/medethics-2020-106504

28. McDougall RJ, Gillam L, Ko D, et al Balancing health worker well-being and duty to care: an ethical approach to staff safety in COVID-19 and beyond Journal of Medical Ethics Published Online First: 2020. doi: $10.1136 /$ medethics-2020-106557

29. Gupta L, Goel A. COVID-19 at the intersections of science, morality and practice - reflections of the physician's soul. J R Coll Physicians Edinb. 2020;50(3):274-6.

30. Ahmed S, Anirvan P. The true meaning of plagiarism. Indian J Rheumatol 2020;15:155-8

31. Misra DP, Agarwal V. Blaming the peer reviewer: Don't shoot the messenger!! Indian J Rheumatol 2020;15:162-4

32. Liew JW, Bhana S, Costello W, Hausmann JS, Machado PM, Robinson PC, et al. The COVID-19 Global Rheumatology Alliance: evaluating the rapid design and implementation of an international registry against best practice. Rheumatology (Oxford). 2020; doi:10.1093/rheumatology/keaa483

33. Hurst JR, Agarwal G, van Boven JFM on behalf of the GACD Multi-Morbidity Working Group, et al. Critical review of multimorbidity outcome measures suitable for low-income and middle-income country settings: perspectives from the Global Alliance for Chronic Diseases (GACD) researchers. BMJOpen 2020;10:e037079. doi: 10.1136/bmjopen-2020-037079

34. Bussières A, Hartvigsen J, Ferreira ML, et al. Adverse childhood experience and adult persistent pain and disability: protocol for a systematic review and meta-analysis. Syst Rev. 2020;9:215. Published 2020. doi: 10.1186/s13643-020-01474-8

35. Edridge, A.W.D., Kaczorowska, J., Hoste, A.C.R. et al. Seasonal coronavirus protective immunity is short-lasting. Nat Med (2020). https://doi.org/10.1038/s41591-020-1083-1

36. Nakatani, H., Katsuno, K. \& Urabe, H. Global health landscape challenges triggered by COVID-19. Inflamm Regener 40, 34 (2020). https://doi.org/10.1186/s41232-020-00144-5

37. Jahangiri M, Cousins R, Gharibi V. Let's get back to work: Preventive biological cycle management of COVID-19 in the workplace. Work. 2020;66(4):713-716. doi: 10.3233/WOR-203217. PMID: 32925132.

38. Regli A, Sommerfield A, von Ungern-Sternberg BS. The role of fit testing N95/FFP2/FFP3 masks: a narrative review. Anaesthesia. 2020. doi: 10.1111/anae.15261. Epub ahead of print. PMID: 32932556.

39. Stubbs T, Kring W, Laskaridis C, Kentikelenis A, Gallagher K. Whatever it takes? The global financial safety net, Covid-19, and developing countries. World Dev. 2021;137:105171. doi:10.1016/j. worlddev.2020.105171

40. Agarwal V, Sharma S, Gupta L, et al. COVID-19 and Psychological Disaster Preparedness - An Unmet Need [published online ahead of print, 2020]. Disaster Med Public Health Prep. 2020;1-4. doi:10.1017/ dmp.2020.219

41. Kimhi S, Marciano H, Eshel Y, Adini B. Recovery from the COVID-19 pandemic: Distress and resilience. Int J Disaster Risk Reduct. 2020;50:101843. doi:10.1016/j.ijdrr.2020.101843 